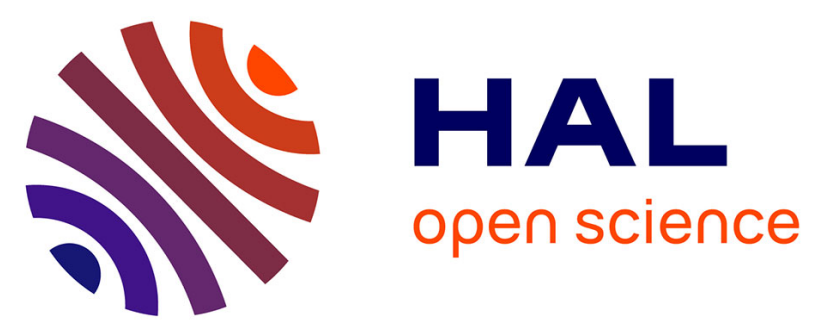

\title{
Complete cytogenetic remission after decitabine treatment in a patient with secondary AML harbouring high gene methylation and high global DNA methylation
}

Ulrich Lehmann, Christiane Dobbelstein, Martin Fenner, Daniel Römermann, Britta Hasemeier, Kathleen Metzig, Doris Steinemann, Guntram Büsche, Jürgen Krauter, Arnold Ganser, et al.

\section{To cite this version:}

Ulrich Lehmann, Christiane Dobbelstein, Martin Fenner, Daniel Römermann, Britta Hasemeier, et al.. Complete cytogenetic remission after decitabine treatment in a patient with secondary AML harbouring high gene methylation and high global DNA methylation. Annals of Hematology, 2008, 88 (3), pp.275-277. 10.1007/s00277-008-0584-7 . hal-00486526

\section{HAL Id: hal-00486526 \\ https://hal.science/hal-00486526}

Submitted on 26 May 2010

HAL is a multi-disciplinary open access archive for the deposit and dissemination of scientific research documents, whether they are published or not. The documents may come from teaching and research institutions in France or abroad, or from public or private research centers.
L'archive ouverte pluridisciplinaire HAL, est destinée au dépôt et à la diffusion de documents scientifiques de niveau recherche, publiés ou non, émanant des établissements d'enseignement et de recherche français ou étrangers, des laboratoires publics ou privés. 


\title{
Complete cytogenetic remission after decitabine treatment in a patient with secondary AML harbouring high $p 15^{I N K 4 b}$ gene methylation and high global DNA methylation
}

\author{
Ulrich Lehmann • Christiane Dobbelstein • \\ Martin Fenner • Daniel Römermann • \\ Britta Hasemeier • Kathleen Metzig • \\ Doris Steinemann • Guntram Büsche • \\ Jürgen Krauter • Arnold Ganser • Hans Kreipe
}

Received: 29 April 2008 / Accepted: 28 July 2008 / Published online: 13 August 2008

(C) Springer-Verlag 2008

\section{Dear Editor,}

Myeloid neoplasias are characterized by extensive epigenetic aberrations, namely aberrant promoter hypermethylation [1]. Therefore, several different treatment regiments have been developed which aim at the reversion of aberrant DNA methylation in patients with MDS or acute myeloid leukaemia [2].

Raj et al. [3] recently reported that MDS patients with a high methylation level of the $p 15^{I N K 4 b}$ gene did not respond to demethylation therapy using azacitidine. Accordingly, they suggested a threshold of $>24 \%$ methylation of the $p 15^{I N K 4 b}$ gene and absence of $p 15^{I N K 4 b}$ mRNA expression for consideration of alternative dosing or combination therapy.

Here, we present a patient with secondary AML with high $p 15^{I N K 4}$ gene methylation and also high global DNA methylation level who responded very well to four courses

U. Lehmann $(\bowtie) \cdot$ D. Römermann • B. Hasemeier · K. Metzig •

G. Büsche $\cdot$ H. Kreipe

Institute of Pathology, Medizinische Hochschule Hannover,

Carl-Neuberg-Str. 1,

D-30625 Hannover, Germany

e-mail: Lehmann.Ulrich@MH-Hannover.de

C. Dobbelstein $\cdot$ M. Fenner $\cdot$ J. Krauter $\cdot$ A. Ganser

Department of Hematology, Hemostasis, Oncology, and Stem Cell Transplantation,

Medizinische Hochschule Hannover,

Hannover, Germany

D. Steinemann

Institute of Cell and Molecular Pathology,

Medizinische Hochschule Hannover,

Hannover, Germany of decitabine, an azacitidine analogue that also irreversibly inhibits DNA methyltransferase activity.

A 60-year-old Caucasian male was transferred to our department for further evaluation and therapy of transfusion-dependent pancytopenia and infectious complications. Two months earlier, the patient was diagnosed with MDS in another hospital. On admission, the patient had dyspnoea and was febrile $\left(39.5^{\circ} \mathrm{C}\right)$. Lung auscultation revealed crackles bilaterally and chest X-ray was consistent with a bilateral pneumonia. He also had epistaxis, mucosal and gastrointestinal bleeding. Blood counts showed marked pancytopenia: WBC $2.8 \times 10^{9} / 1$ (ANC $1.6 \times 10^{9} / 1,3 \%$ blasts), haemoglobin $5.3 \mathrm{~g} / \mathrm{dl}$, platelets $3 \times 10^{9} / 1$. Bone marrow evaluation revealed a secondary acute myeloid leukaemia with $50 \%$ blasts. Cytogenetic analysis showed a complex karyotype including monosomy 7: 41-45, XY, del (3)(p14), del(4)(q2?6), -5, -7, add(15)(q2?6), +mar, +1 [cp9]/46, XY [7].

The pneumonia was treated empirically with antibiotics and antifungals and the patient received transfusions for severe anaemia and thrombocytopenia. The patient was not considered eligible for intensive chemotherapy and therefore treatment with decitabine was started after clinical improvement of the pneumonia. Treatment consisted of the standard decitabine regimen ( $15 \mathrm{mg} / \mathrm{qm}$ TID i.v. for 3 days) and was well tolerated. After the first course of decitabine the patient achieved a complete remission with less than $5 \%$ blasts in the bone marrow and normalized peripheral cell counts (WBC $6,6 \times 10^{9} / 1$ with ANC $3,8 \times 10^{9} / 1$ and no blasts, haemoglobin $10,2 \mathrm{~g} / \mathrm{dl}$, platelets $\left.175 \times 10^{9} / \mathrm{l}\right)$. The cytogenetic examination after two decitabine courses revealed a normal karyotype without evidence of the former monosomy 7 . 
The upper panel in Fig. 1 shows how the platelet count and haemoglobin reach normal values after therapy. This was paralleled by a decrease in global DNA methylation and in $p 15^{I N K 4}$ gene methylation (Fig. 1, lower panel). As a surrogate marker for the global DNA methylation level, the methylation status of LINE-1 sequences was measured quantitatively by Pyrosequencing ${ }^{\mathrm{TM}}$. A decrease in LINE-1 methylation from $78.5 \%$ to $66 \%$ (after the fourth cycle) means that the global DNA methylation is reduced by approximately $16 \%$, affecting the chromatin structure of thousands of loci. Hypermethylation of the tumour suppressor gene $p 15^{I N K 4 b}$ vanished completely during remission and haematological improvement. This was accompanied by an increase in $p 15^{I N K 4 b}$ mRNA expression as measured by quantitative real-time RT-PCR (see Fig. 1, lower panel).

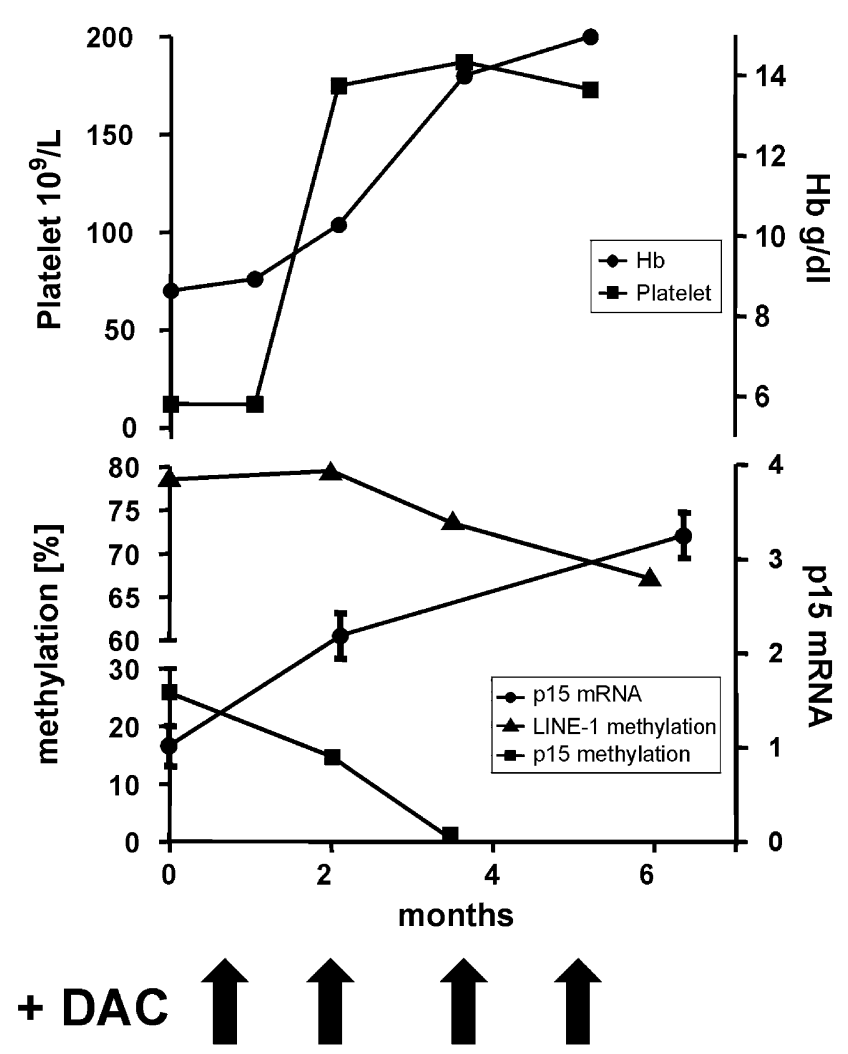

Fig. 1 The upper panel shows the increase in platelet count and haemoglobin value as indicators for haematological improvement during decitabine therapy. The lower panel shows the decrease in global (LINE-1) and gene-specific $\left(p 15^{I N K 4 b}\right)$ DNA methylation and the concomitant up-regulation of the $p 15^{I N K 4 b}$ gene mRNA expression during decitabine therapy. For measurement of LINE-1 methylation level by Pyrosequencing ${ }^{\mathrm{TM}}$, the LINE-1 primer set was purchased from Biotage (Uppsala, Sweden) and the analysis was performed following the protocol provided. $p 15^{I N K 4}$ gene methylation was determined essentially as described [4]. Quantification of $p 15^{I N K 4 b}$ mRNA using real-time RT-PCR was performed essentially as described [5]. For relative quantification the expression level in the first biopsy was set equal to one
Eight months after initiation of decitabine treatment (3 months after the last decitabine course) a relapse was diagnosed. The patient received intensive reinduction chemotherapy with mitoxantrone $\left(12 \mathrm{mg} / \mathrm{m}^{2}\right.$ day 1 and 2$)$, topotecan $\left(1.5 \mathrm{mg} / \mathrm{m}^{2}\right.$ day 3 until day 7$)$ and cytarabine $\left(1,000 \mathrm{mg} / \mathrm{m}^{2}\right.$ day 3 until day 7$)$. After achieving partial remission, he underwent allogeneic transplantation from a matched unrelated donor (4 months after the last decitabine course). The conditioning was performed as follows: day -16 until day -12 : clofarabine $\left(30 \mathrm{mg} / \mathrm{m}^{2}\right)$ and cytarabine $\left(1,000 \mathrm{mg} / \mathrm{m}^{2}\right)$; day -4 : total body irradiation with $4 \mathrm{~Gy}$; day -3 and -2 : cyclophosphamide $(60 \mathrm{mg} / \mathrm{kg})$, and day -3 until day -1 : rabbit antithymocyte globulin $(20 \mathrm{mg} / \mathrm{kg})$; ciclosporine and mycophenolate mofetil were given for GvHD prophylaxis. Thirteen months after allogeneic transplantation, the patient is alive and in remission with chronic GvHD after receiving donor lymphocyte infusions for progressive mixed chimerism 4 months after transplantation.

These results indicate that inclusion or exclusion criteria based on quantitative methylation analyses have to be questioned. In contrast to the suggestions made by Raj et al. [4], one could argue that higher methylation levels at the beginning of the treatment with demethylating agents might predict a favourable response, at least in patients with secondary leukaemia. Another patient treated in the same manner in our institution but not responding at all to the decitabine treatment, had a comparable LINE-1 methylation level at the start of therapy but a much lower $p 15^{I N K 4 b}$ gene methylation. Both LINE-1 and $p 15^{I N K 4 b}$ methylation increased during the ineffective therapy (data not shown).

Clinically fit patients that achieve a complete remission with decitabine treatment should be considered for allogeneic stem cell transplantation. Currently, it cannot be decided with certainty whether eligibility of MDS and AML patients for epigenetic therapy should be based on quantification of gene methylation. Further studies are definitely needed in this field.

Acknowledgements This study was supported by a grant from the Deutsche Krebshilfe, Dr. Mildred Scheel Stiftung (to UL and HK).

\section{References}

1. Boultwood J, Wainscoat JS (2007) Gene silencing by DNA methylation in haematological malignancies. $\mathrm{Br} \mathrm{J}$ Haematol 138:3-11 doi:10.1111/j.1365-2141.2007.06604.x

2. Griffiths EA, Gore SD (2008) DNA methyltransferase and histone deacetylase inhibitors in the treatment of myelodysplastic syndromes. Semin Hematol 45:23-30 doi:10.1053/j.seminhematol. 2007.11.007 
3. Raj K, John A, Ho A, Chronis C, Khan S, Samuel J et al (2007) CDKN2B methylation status and isolated chromosome 7 abnormalities predict responses to treatment with 5-azacytidine. Leukemia 21:1937-1944 doi:10.1038/sj.leu.2404796

4. Brakensiek K, Wingen LU, Langer F, Kreipe H, Lehmann U (2007) Quantitative high-resolution $\mathrm{CpG}$ Island Mapping with Pyrosequencing $^{\mathrm{TM}}$ reveals disease-specific methylation patterns of the
CDKN2B gene in myelodysplastic syndrome and myeloid leukemia. Clin Chem 53:17-23 doi:10.1373/clinchem.2007.072629

5. Tessema M, Langer F, Dingemann J, Ganser A, Kreipe H, Lehmann U (2003) Aberrant methylation and impaired expression of the p15(INK4b) cell cycle regulatory gene in chronic myelomonocytic leukemia (CMML). Leukemia 17:910-918 doi:10.1038/sj. leu. 2402891 